\title{
Effects of the origin and caponisation on carcass and meat traits in cockerels and capons aged 18 weeks
}

\author{
Marek Adamski, Joanna Kuźniacka, Mirosław Banaszak \\ University of Science and Technology in Bydgoszcz, Faculty of Animal Breeding and Biology, \\ Department of Poultry Breeding and Animal Material Evaluation, Bydgoszcz, Poland
}

Received January 25, 2016

Accepted August 31, 2016

\begin{abstract}
The aim of the present research was to evaluate the effect of the origin and caponisation on selected slaughter traits and quality indicators of meat in cockerels and capons of strains N88 (New Hampshire), R55 (Rhode Island Red), S11 (Sussex), and P55 (Plymouth Rock). The slaughter yield, breast muscle weight, percentage share of muscles in total in the carcasses, and fatness in general did not differ between the cockerels and capons within the evaluated strains. The trait that mostly distinguished cockerels from capons of strain N88 was the weight of leg muscles. Similarly, the fat content of carcasses expressed with the weight and percentage share of the skin with subcutaneous fat and abdominal fat did not differ between the evaluated groups of cockerels and capons. However, the weight of the leg muscles varied depending on the origin of cockerels and capons. As for the physiochemical properties of meat as well as its chemical composition, no significant differences were recorded in 18-week-old birds. The only obvious effect of the origin and caponisation was found on varied contents of fat in breast muscles in cockerels of strains N88 and P55, and capons of strain P55.
\end{abstract}

Poultry, rearing, slaughter yield, meat, fatness, collagen

As for the hatch of chicks allocated to be used as laying hens for reproductive and productive flocks, one obtains, on average $50 \%$ of cockerels that do not attract interest in further use and, most often, being one-day chicks, they are used as feed for carnivorous animals or they must be disposed of, which poses major problems for poultry hatching plants (Klein et al. 2003; Murawska et al. 2005). Some authors (Kosarachukwu et al. 2010; Taugan et al. 2013 b) recommend materials derived from rearing chickens for slaughter of various origin and of different housing systems.

Considering the tastes of contemporary consumers, searching for alternative materials and products, it seems justifiable to take up the problem of the management of mid-heavy cockerels in the production of capons, which is justified, especially since the meat received from capons is more delicate, showing outgrown fat tissue, with greater taste values (Zawacka and Murawska 2013; Adamski et al. 2016).

The slaughter traits, physiochemical properties and chemical composition of meat, depending on the origin, age and the keeping system in capons compared to cockerels, were evaluated in various papers (Tor et al. 2002; Siri et al. 2009; Symeon et al. 2010; Volk et al. 2011). The research shows i.a. that caponisation significantly increases the contents of fat in muscles which, in turn, enhances its tenderness. As for the effect of caponisation on the body weight, muscle content and physiochemical properties of meat, observations by the abovementioned authors differ.

The aim of the present research has been to evaluate the effect of caponisation on selected slaughter traits and the quality indicators of meat of the most popular strains of mid-heavy hens in the country, originated from New Hampshire, Rhode Island Red, Sussex and Plymouth Rock. 


\section{Materials and Methods}

The experimental material was made up of a total of 96 cockerels and capons representing four breeding strains from the Breeding Farm at Rszew, Poland. Cockerels were divided according to the origin into the following groups, 24 pieces each: N88 (New Hampshire), R55 (Rhode Island Red), S11 (Sussex) and P55 (Plymouth Rock). In the $12^{\text {th }}$ week of rearing in each group, a licensed veterinary doctor performed caponisation of half of the number of cockerels. In total, the treatment was performed in 48 birds (12 from each line). The treatment and the performance method complied with Regulation of Committee (EC) 543/2008. All birds designated to caponised groups were restrained from the feed for $12 \mathrm{~h}$ before the surgical operation. The caponisation procedure was carried out by a licensed veterinarian accompanied by an assistant and by using surgical methods. The surgery was performed after using the anaesthetic Bioketan (10\% ketamine). Two incisions were made on both sides of the body along the hip joint from the top about $1-2 \mathrm{~cm}$ from the transverse side, towards the edge between the second to last and last ribs. After a rib spreader was inserted, the air sac was cut, the intestines were moved aside and the testicles were cut off using a loop. Capons of strain N88 were allocated to another group, as well as capons of strains R55, S11, and P55.

The birds were reared until the $18^{\text {th }}$ week of life in regulated environmental condition, in deep litter, without the possibility of free ranging. All the environmental indicators complied with the Technical Guidelines for Rosa Hens (2010). Throughout rearing, the birds were fed ad libitum and enjoyed unlimited access to water. Birds' nutrition complied with the current guidelines (Poultry Nutrition Standard 2005).

At the end of rearing in the $18^{\text {th }}$ week, dissection of the whole carcasses of cockerels and capons from each group was performed using the method described by Adamski et al. (2015). Right after slaughter, a sample was taken from each bird from the left superficial breast muscle along the fibre line to assay intramuscular fat. Each sample was individually frozen in liquid nitrogen at a temperature of $-195.8^{\circ} \mathrm{C}$. Then the carcasses were plucked and 15 min after slaughter the $\mathrm{pH} 1.5$ value of breast muscles was measured (Elmetron $\mathrm{pH}$ meter, Poland, 2010). Before dissection after about 18 -h carcass cooling $\left(+4^{\circ} \mathrm{C}\right)$ the reaction $(\mathrm{pH} 2.4)$ of breast muscles was measured. The carcasses were eviscerated, separating offal (heart, stomach and liver) and the inedible parts, then the neck without skin, leg and breast muscles, the skin with subcutaneous fat from the whole carcass, abdominal fat, wings and the rest of the carcass.

Once the dissection was completed, the breast and leg muscles were evaluated in terms of colour. The colour of both types of muscles in the reflected light was measured using colorimeter CR 400 provided by MINOLTA (Konica Minolta Poland, Japan, 2013), with the colour pattern L*, a*, b* (L* - brightness variable, a* - red colour variable, $b^{*}$ - yellow colour variable). The water holding capacity of the breast and leg muscles was also evaluated with the modified Grau and Hamm method (1952). Chemical composition and the content of collagen in the breast and leg muscles were assayed using the method of transmission spectrometry in near infra-red with the analyser of the physiochemical composition of meat FoodScan ${ }^{\mathrm{TM}}$ (Foss Poland, Denmark). The content of intramuscular fat was assayed with the microscope preparations stained with SUDAN B5 (Chempur, Poland). The number of intramuscular fat cells was determined with microscope Scope A1 AXIO (Zeiss Poland, Switzerland), magnified $0.5 \times 20$, and the percentage share was defined with the image analysis system ZEN 2012 (Zeiss Poland, Switzerland).

Applying the STATISTICA PL 10.0 software (2011), we calculated mean values (x) and standard deviations (SD) of the traits studied, by exposing them to the analysis of variance and the evaluation of significance of the differences with the Sheffe's test. The influence of the interaction of the origin and caponisation was determined.

\section{Results}

The capon body weights did not show significant differences $(P>0.05)$ depending on the birds' origin, only capons of the strain R55 weighed significantly the least compared to the other groups (Table 1). The analysis of the mean values of slaughter traits in the $18^{\text {th }}$ week of rearing in cockerels and capons shows that the greatest weight of eviscerated carcass with neck within the compared cockerels groups was found for strain S11, whereas the lowest was found for N88. Comparison of that trait among the groups of capons revealed that the carcasses of birds of strains N88, S11 and P55 demonstrated similar weight. Exceptions were the carcasses of R55 capons where the weight was significantly the lowest $(958.3 \mathrm{~g})$. The carcasses of N88 capons weighed on average $251.1 \mathrm{~g}(P>0.05)$, which was more than cockerels from that strain. However, no such differences were found $(P>0.05)$ between cockerels and capons of the other strains. Similarly, the slaughter yield did not differ between cockerels and capons within the strains. Cockerels of strains S11 and P55 showed a significantly higher slaughter yield in the $18^{\text {th }}$ week of rearing compared to N88 cockerels. 


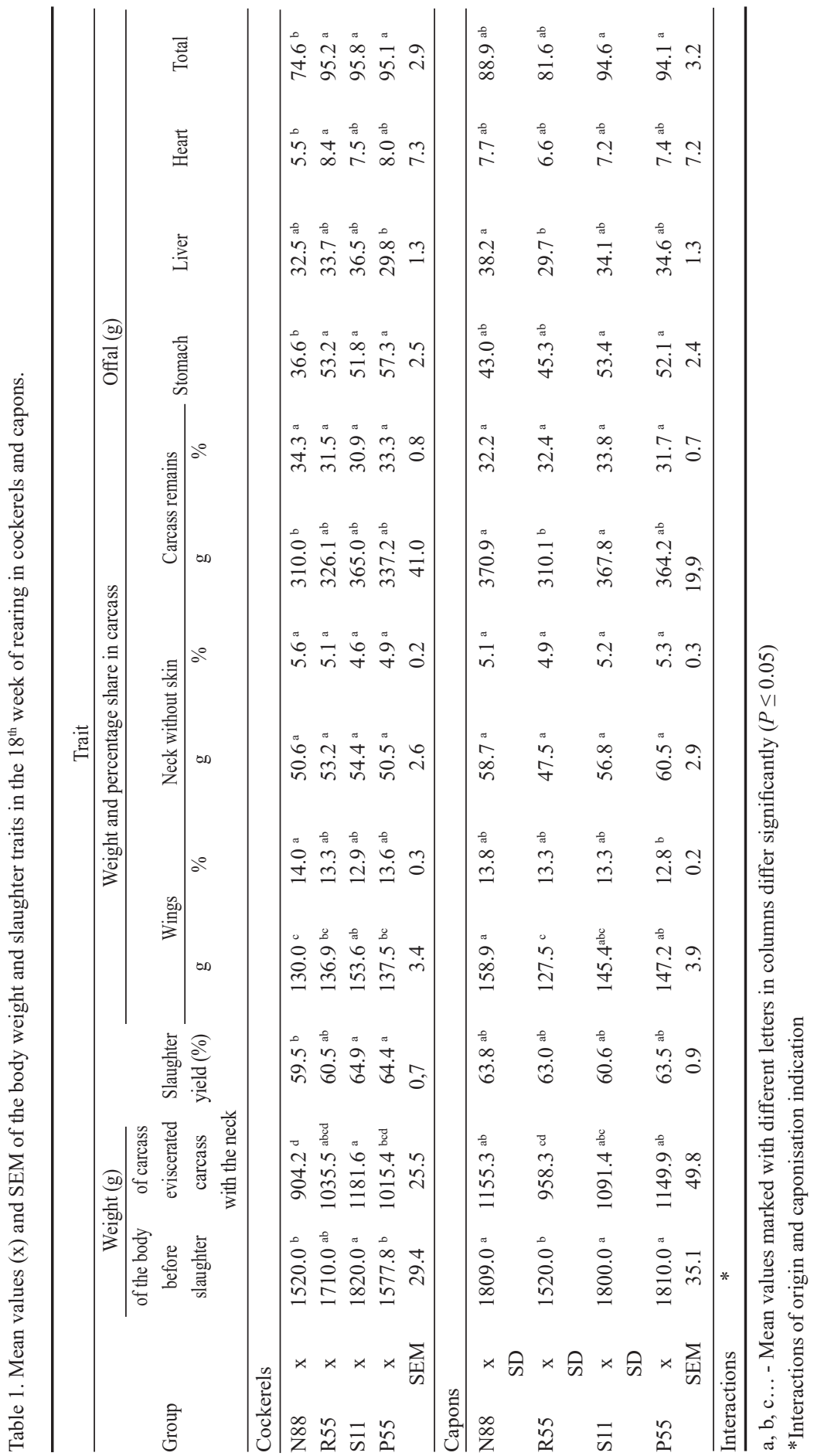




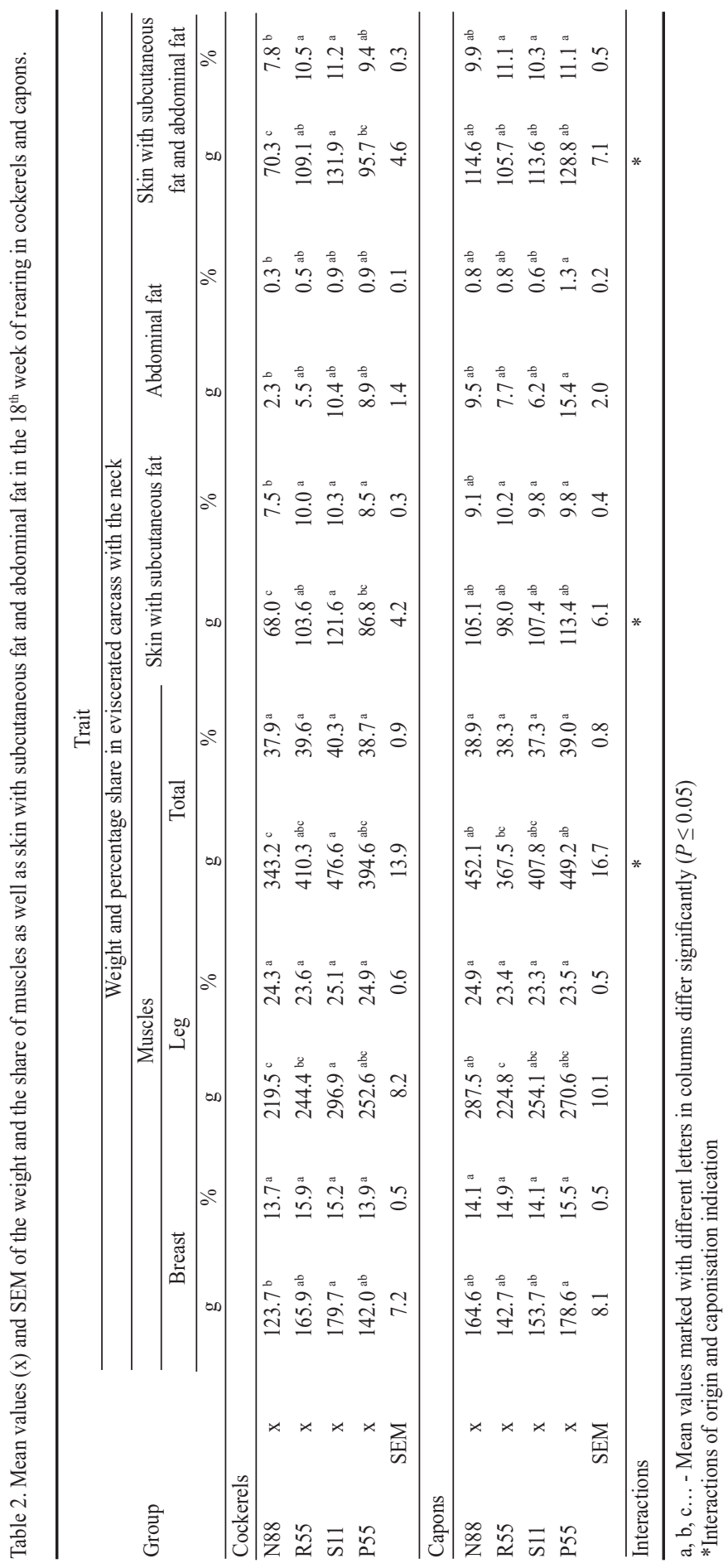


A lack of significant differences between cockerels and capons of all the strains was found in the weight and the percentage share of the neck in the carcass as well as the percentage share of the rest of the carcass. Cockerels of strain N88 were the only ones that showed a significantly lower weight $(P>0.05)$ of the rest of the carcass compared to capons of the same strain. Within both groups of cockerels and capons, no significant differences were found in that trait. The weight of the remaining carcass in N88 cockerels and R55 capons must have been due to low body weight prior to slaughter and thus the weight of eviscerated carcasses with the neck. The lowest mean offal weight of all the groups evaluated was also found in N88 cockerels, which was affected by the lowest mean weight of the stomach and the heart (Table 1).

Table 2 demonstrates that cockerels from strain S11 showed the highest weight of breast muscles, whereas the lowest one was found in strain N88 $(P \leq 0.05)$. The highest mean weight of breast muscles of all the capons was found in those birds. No significant differences were found in the weight of breast muscles between cockerels and capons within the respective strains. However, the weight of leg muscles clearly differed between cockerels and capons of strain N88, which confirms a positive effect of the caponization in birds of the same strain. The total muscle content in the carcasses of cockerels expressed with the mean weight of breast and leg muscles was highest in strain S11; however, it significantly differed only from cockerels of strain N88, unlike capons derived from N88 cockerels showed the best muscle content. However, the differences between capons of the other strains in terms of that trait were non-significant $(P \leq 0.05)$. The carcass fat content expressed by the weight and percentage share of skin with subcutaneous fat and abdominal fat did not differ between the groups of cockerels and capons under study. The weight of skin with subcutaneous fat in the carcasses of cockerels and capons representing strain N88 was an exception, which affected the differences in their total fat content.

In terms of physiochemical traits of meat, no significant differences were found in 18-week-old birds (Table 3). The water holding capacity was an exception. The breast muscles in cockerels N88 and R55 demonstrated a greater water leak compared to the muscles of cockerels S11. In the $18^{\text {th }}$ week of rearing, greater saturation with yellow colour was also found in leg muscles compared to breast muscles, which proves that there is no influence of the origins of birds and the treatment of caponisation on the quality of meat characteristics.

The breast muscles in cockerels of strain N88 showed a significantly higher water content compared to the breast muscles in cockerels of strains R55 and P55 (Table 4). Of all the capons, the highest water content $(76.3 \%)$ was identified in those of strain N88; the value significantly differed from the other capon groups. Caponisation did not influence the protein content in breast muscles in strains R55 and S11. However, capons of strain P55 showed a significantly higher share (by $1.3 \%$ ) of protein in breast muscles compared to cockerels of the same strain; in contrast, capons of strain N88 showed a significantly lower one compared to cockerels of the same strain.

In 18-week-old cockerels and capons of strains R55 and S11, no clear effect of either the origin or caponisation was demonstrated on the fat content in breast muscles (Table 4). However, in the other groups of evaluated cockerels of strains N88, P55 and capons of strain P55, significant differences in the values of that trait confirmed a clear effect of the origin and caponisation on the fat content in breast muscles. Only in birds of strain S11 caponisation significantly affected the collagen content in breast muscles (Table 4). Such differences $(P \leq 0.05)$ were not recorded in the collagen content in leg muscles. Similar collagen content in leg muscles was found in both cockerels and capons.

Leg muscles varied significantly in terms of water content depending on the origin of cockerels (Table 4). In birds of strains N88 and P55, caponisation showed a significantly $(P \leq 0.05)$ decreased content of water and protein in leg muscles in capons N88, and 


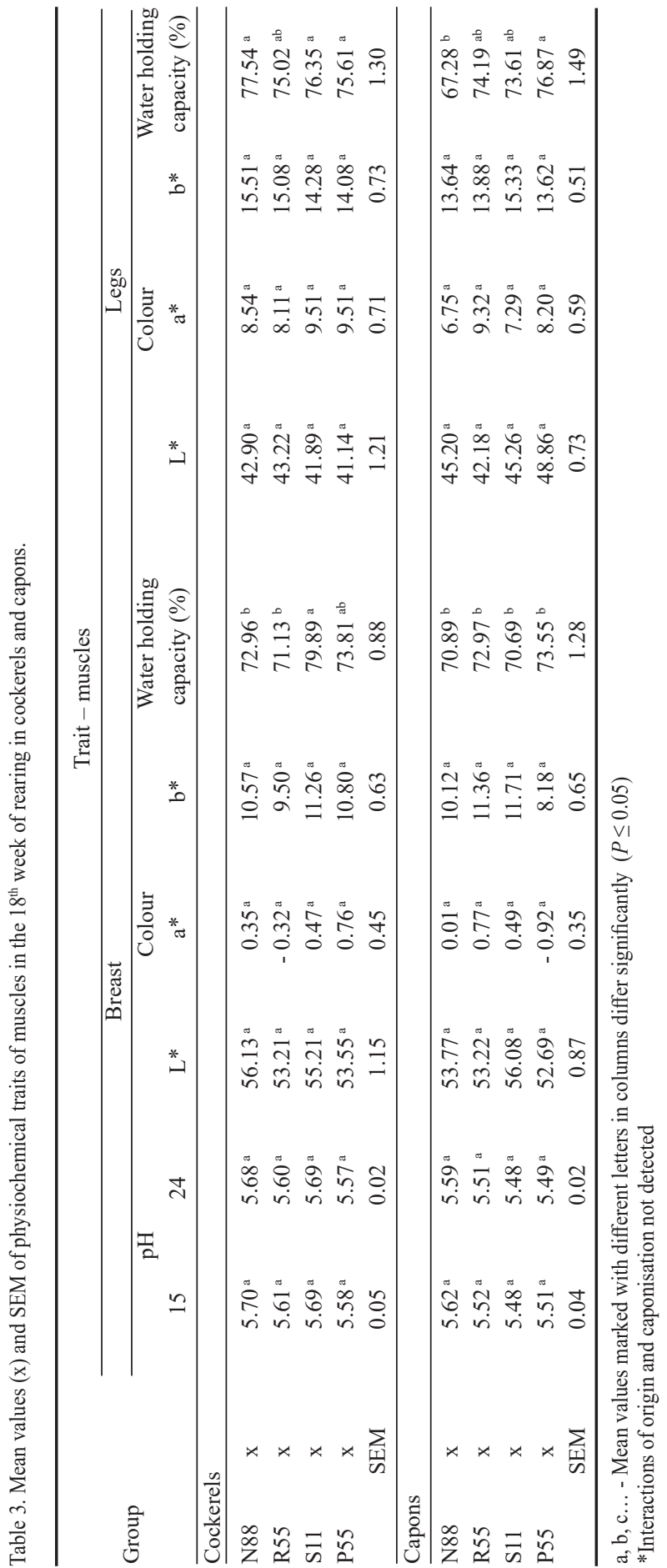

an increased protein content in cockerels P55 compared to cockerels of those strains. Within the groups of cockerels, the protein content in leg muscles differed significantly between strains N88 and S11. However, within capons, the protein content in leg muscles was the highest in birds P55 compared to the other groups. It was also reported that the origin of birds differed $(P>0.05)$ in the groups in terms of the content of fat in leg muscles. Similarly as the origin, also caponisation affected the birds of strains N88, R55 and P55; increasing the fat content in leg muscles compared to the cockerels of the same strains. Analysis of the mean number of fat cells (Plate IV, Fig. 1) showed that after 18 weeks of rearing, the number of fat cells per $1 \mathrm{~mm}^{2}$ was non-significantly $(P<0.05)$ higher in the pectoralis superficialis muscle in capons, from 3.7 to 4.5 , than in the muscles of cockerels, which amounted to from 3.2 to 4.0 .

\section{Discussion}

Cockerels and capons in the present experiment showed similar mean values of slaughter traits to the caponised birds evaluated at the same age (the $18^{\text {th }}$ week) by Shao et al. (2009); whereas both cockerels and capons of the lines evaluated in the present experiment showed a lower weight of the body and eviscerated carcass with the neck compared to the 18-week-old fourstrain crossbreds (KA6482), 
originating from Rhode Island Red and Rhode Island White as reported by Murawska et al. (2005).

Varied fat content in cockerels and capons as found in the present research was also reported by Symeon et al. $(2010 ; 2012 ; 2013)$ in slowly-growing slaughter chickens in the $18^{\text {th }}$ week of rearing. Symeon et al. (2013) reported capons with a significantly $(P \leq 0.05)$ higher weight of breast and leg muscles compared to cockerels, whereas the results of our research confirm such differences only for the bird strain N88. In a study conducted by Murawska et al. (2005), crossbred cockerels aged 18 weeks, originating from four strains of Rhode Island Red and Rhode Island White, had better musculature and adiposity compared to birds from the pure strain evaluated in our study. It was the result of a higher total body weight of the crossbreds.

Table 4. Mean values (x) and SEM of the chemical composition of meat and collagen in the $18^{\text {th }}$ week of rearing in cockerels and capons.

\begin{tabular}{|c|c|c|c|c|c|c|c|c|c|}
\hline \multirow{4}{*}{ Group } & \multicolumn{9}{|c|}{ Trait } \\
\hline & \multicolumn{9}{|c|}{ Content in muscles (\%) } \\
\hline & & \multicolumn{4}{|c|}{ Breast } & \multicolumn{3}{|c|}{ Leg } & \multirow[b]{2}{*}{ Collagen } \\
\hline & & Water & Protein & Fat & Collagen & Water & Protein & Fat & \\
\hline \multicolumn{10}{|l|}{ Cockerels } \\
\hline N88 & $\begin{array}{c}x \\
\text { SD }\end{array}$ & $76.1^{\mathrm{a}}$ & $22.8^{c}$ & $1.1^{\mathrm{e}}$ & $0.9^{a b}$ & $76.3^{a}$ & $20.3^{b}$ & $3.1^{\mathrm{f}}$ & $1.6^{\mathrm{a}}$ \\
\hline R55 & $\begin{array}{c}\mathrm{x} \\
\mathrm{SD}\end{array}$ & $74.8^{\mathrm{d}}$ & $23.8^{b}$ & $1.5^{\mathrm{cd}}$ & $1.0^{\mathrm{ab}}$ & $74.2^{\mathrm{d}}$ & $20.3^{b c}$ & $4.6^{\mathrm{d}}$ & $1.6^{\mathrm{a}}$ \\
\hline S11 & $\begin{array}{c}x \\
\text { SD }\end{array}$ & $75.9^{b}$ & $22.5^{\mathrm{d}}$ & $1.7^{b c}$ & $0.9^{b}$ & $74.7^{c}$ & $20.1^{c}$ & $4.9^{c}$ & $1.6^{\mathrm{a}}$ \\
\hline \multirow[t]{2}{*}{ P55 } & $\begin{array}{c}\mathrm{x} \\
\mathrm{SD}\end{array}$ & $75.4^{c}$ & $23.0^{c}$ & $1.4^{\mathrm{d}}$ & $0.9^{b}$ & $75.2^{b}$ & $20.2^{b c}$ & $4.1^{\mathrm{e}}$ & $1.5^{\mathrm{a}}$ \\
\hline & SEM $^{\mathrm{b}}$ & 0.08 & 0.02 & 0.05 & 0.03 & 0.06 & 0.10 & 0.02 & 0.03 \\
\hline \multicolumn{10}{|l|}{ Capons } \\
\hline N88 & $\begin{array}{c}\mathrm{x} \\
\mathrm{SD}\end{array}$ & $76.3^{a}$ & $22.2^{\mathrm{e}}$ & $1.9^{b}$ & $1.1^{\mathrm{ab}}$ & $74.9^{b}$ & $19.5^{\mathrm{d}}$ & $5.1^{b}$ & $1.7^{a}$ \\
\hline R55 & $\begin{array}{c}\mathrm{x} \\
\mathrm{SD}\end{array}$ & $74.7^{\text {de }}$ & $23.7^{b}$ & $1.7^{b c}$ & $1.0^{\mathrm{ab}}$ & $74.0^{\mathrm{d}}$ & $20.2^{b c}$ & $5.2^{\mathrm{a}}$ & $1.6^{\mathrm{a}}$ \\
\hline S11 & $\begin{array}{c}x \\
\text { SD }\end{array}$ & $75.9^{b}$ & $22.5^{\mathrm{d}}$ & $1.7^{\mathrm{c}}$ & $1.1^{\mathrm{a}}$ & $74.7^{c}$ & $19.7^{\mathrm{d}}$ & $5.0^{b c}$ & $1.6^{\mathrm{a}}$ \\
\hline P55 & $\begin{array}{c}\mathrm{x} \\
\text { SEM }\end{array}$ & $\begin{array}{c}74.3^{\mathrm{e}} \\
0.04\end{array}$ & $\begin{array}{r}24.3^{\mathrm{a}} \\
0.03\end{array}$ & $\begin{array}{l}2.3^{\mathrm{a}} \\
0.03\end{array}$ & $\begin{array}{l}1.0^{\mathrm{ab}} \\
0.03\end{array}$ & $\begin{array}{r}74.2^{\mathrm{d}} \\
0.06\end{array}$ & $\begin{array}{r}20.7^{\mathrm{a}} \\
0.13\end{array}$ & $\begin{array}{l}4.9^{\mathrm{c}} \\
0.03\end{array}$ & $\begin{array}{l}1.6^{\mathrm{a}} \\
0.02\end{array}$ \\
\hline Interactions & & & $*$ & $*$ & $*$ & $*$ & $*$ & $*$ & \\
\hline
\end{tabular}

a, b, c... - Mean values marked with different letters in columns differ significantly $(P \leq 0.05)$

*Interactions of origin and caponisation indication

In the 18-week-old cockerels and capons under study, no significant differences were noted in the physiochemical traits of meat, except for the water holding capacity, which can prove that there is no influence of the origins of the birds and the caponization treatment on the quality of meat characteristics, which was confirmed by earlier reports of Symeon et al. (2012). It showed no clear variation in $\mathrm{pH}$ values, the colour brightness of breast muscles as well as their saturation with red and yellow colour in 18-week-old cockerels 
and capons. However, in capons evaluated by Diaz et al. (2010), the water leak expressed with water absorption was $18.6 \%$ in capons, and $23.8 \%$ in cockerels, and it was much lower than in the present experiment. The differences, however, could have been due to different origins of cockerels and capons in the present research, similarly as in the muscle colour evaluation using the method L*a*b*.

Other studies (Jaturasitha et al. 2008a; 2008b) as well as our study showed a very clear $(P>0.05)$ effect of the birds' origin on the chemical composition of breast and leg muscles in 18-week-old birds. In turn, unlike in the present research, Chen et al. (2007) demonstrated that caponisation had no significant effect on the content of water and protein in bird muscles. The protein content in breast muscles was 23.0 and $23.8 \%$ in cockerels of strain P55, and 20.2 and $20.3 \%$ in cockerels of strain R55. The protein content in leg muscles in cockerels of strains P55 and R55 in our research was higher than that found in other research (Jaturasitha et al. 2008b; Tougan et al. 2013a). The statement that the content of protein in bird muscles depends on their origin has been confirmed by many authors (Klont et al. 1998; Qiao et al. 2002; Chen et al. 2010a,b). Diaz et al. (2013) report their research with slow-growing birds which also did not find significant differences between cockerels and capons in the chemical composition of leg muscles before the $18^{\text {th }}$ week of rearing.

In our research we found a clear effect of the origin and caponisation on the fat content in breast muscles, except for the birds of strains R55 and S11, confirmed by the differences in the values of that trait. The collagen content in breast muscles in cockerels and capons in our experiment was similar to the values recorded by Jaturasitha et al. (2008a,b).

Analysing the mean number of fat cells in breast muscles which, according to other authors (Beaza et al. 1998), has a direct effect on the tenderness and microstructure of meat, our research demonstrated that in the $18^{\text {th }}$ week of rearing the mean number of fat cells in the superficial breast muscle was higher in capons than in cockerels of the lines under study. Together with the changes in the fat content of breast muscles analysed earlier, this finding can suggest a better culinary quality of meat derived from capons than from cockerels.

To sum up, it can be stated that the body weight of 18-week-old cockerels and capons did not differ markedly. In the body weight of capons, no significant differences were demonstrated depending on the birds' origin; only capons of strain R55 weighed significantly the least compared to the other groups. In general, the slaughter yield, breast muscle weight, and carcass fat content did not differ between cockerels and capons within their respective strains. However, one trait clearly differed between cockerels and capons of strain N88, and that was the leg muscle weight. As for physiochemical meat traits, no significant differences were found in 18-week-old birds, except for the water holding capacity. The effect of the origin and caponisation on the content of fat in breast muscles was clear only in the groups of cockerels and capons of strains N88 and P55, whereas caponisation has a non-significant effect $(P<0.05)$ on the mean number of fat cells in the superficial breast muscle which was higher in capons than in cockerels of the evaluated strains.

\section{References}

Adamski M, Kuźniacka J, Banaszak M, Wegner M 2016: The analysis of meat traits of Sussex cockerels and capons (S11) at different ages. Poult Sci 95: 125-132

Baeza E, Guy G, Salichon M, Juin H, Kłosowska D, Eliminowska-Wenda G, Śrutek M, Rosiński A 1998: Influence of feeding systems, extensive $v s$ intensive, on fatty liver and meat production in geese. Arch Geflügel 62: 169-171

Chen KL, Tsay SM, Chiou PWS, Sun CP, Weng BC 2010 a: Effects of caponization and different forms of exogenous androgen implantation on immunity in male chicks. Poult Sci 89: 5

Chen TT, Huang CC, Lee TY, Lin KJ, Chang CC, Chen KL 2010 b: Effect of caponization and exogenous androgen implantation on muscle characteristic of cockerels. Poult Sci 89: 3 
Commission Regulation (EC) 543/2008, 2008: Journal of the European Union. 17. 6. 2008

Diaz O, Rodrígez L, Torres A, Cobos A 2010: Chemical composition and physicochemical properties of meat from capons as affected by breed and age. Span J of Agric Res 8: 91-99

Diaz O, Rodrígez L, Torres A, Cobos A 2013: Composition and physicochemical properties of meat capons feed cereals. J of Integ Agric 12: 1953-1960

Grau R, Hamm R, 1952: Eine einfache Methode zur Bestimmung der Wasserbindung im Fleisch Fleischwirtschaft 4: $295-297$

Jaturashita S, Kayan A, Wicke M 2008 a: Carcass and meat characteristics of cockerels between Thai indigenous compared with improved layer breeds and their crossbred. Archiv Tierzucht 51: 283-294

Jaturasitha S, Srikanchai T, Kreuzer M, Wicke M 2008 b: Differences in carcass and meat characteristics between chicken indigenous to Northern Thailand (Black-Bonded and Thai Native) and imported extensive breeds (Bresse and Rhode Island Red). Poult Sci 87: 160-169

Klein S, Flock D, Ellendorf F 2003: Management of newly hatched male layer chicks - current knowledge on sex determination and sex diagnosis in chicken : potential solutions. World's Poult Sci J 59: 62-64

Klont R E, Brocks L, Eikelenboom G 1998: Muscle fibre type and meat quality. Meat Sci 49: 219-229

Kosarachukwu CO, Okechukwu O, Iheshiulor M, Omede A, Ogbuewu PI 2010: Effect of strain on growth, carcass characteristics and meat quality of broilers reared for 12 weeks. New York Sci J 3: 5

Murawska D, Bochno R, Michalik D, Janiszewska M 2005: Age - related changes in the carcass tissue composition and distribution of meat and fat with skin in carcass of laying - type cockerels. Arch Geflügelk 69: 35-139

Połtowicz K, Doktor J 2012: Effect of slaughter age on performance and meat quality of slow - growing broiler chickens. Ann Anim Sci 12: 62- 631

Poultry Nutrition Standard 2005: Nutrition guidelines and animal feed nutrition value. (Warszawa, Edited by Inst Fizj i Żyw Zw PAN) - in Polish

Qiao M, Fletcher DL, Northcutt JK, Smith DP 2002: The Relationship Between Raw Broiler Breast Meat Color and Composition. Poult Sci 81: 422-427

Shao Y, Wu C, Li J, Zhao C 2009: The effects of different caponization age on growth performance and blood parameters in male Tibetan chicken. Asian J Anim Vet Adv 5: 228-236

Sirri F, Bianchi M, Petracci M, Melluzi A 2009: Influence of partial and complete caponization on chicken meat quality. Poult Sci 88: 1466-1473

Statistica P1 2011: Version 10.0, series 1101

Symeon G K, Mantis F, Bizelis I, Kominakis A, Rogdakis E 2010: Effects of caponization on growth performance, carcass composition, and meat quality of medium growth broilers. Poult Sci 89: 1481-1489

Symeon G K, Mantis F, Bizelis I, Kominakis A, Rogdakis E 2012: Effect of caponization on growth performance, carcass composition and meat quality of males of a layer line. Anim 12: 2023-2030

Symeon G K, Charismiadon M, Mantis F, Bizelis I, Kominakis A, Rogdakis E 2013: Effect of caponization an fat metabolism - related biochemical characteristic of broiler. J Anim Phys Nutr. 97: 162-169

Technical Guidelines for Rosa Hens 2010: Principles of the Rosa care of young hens and breeding. (Konstantynów Łódzki, Eddited by Zarodowa Ferma Kur Rszczew sp. z o. o) - in Polish

Tor M, Estany J, Villalba D, Molina E, Cubiló D 2002: Comparison of carcass composition by parts and tissues between cocks and capons. Anim Res 51: 421-431

Tougan PU, Dahouda M, Salifou CFA, Ahonou GS, Kpodekon MT, Mensah GA, Kossou DNF, Menou C, Kogbeto CE, Lognay G, Thewis A, Youssao IAK 2013a: Relationships between carcass traits and offal components in local poultry populations (Gallus gallus) of Benin. J App Biosci 69: 5510-5522

Tougan PU, Dauouda M, Folakè C, Salifou A, Ahounou SGA, Kpodekon MT, Mensah GA, Thewis A, Karim IYAK 2013b: Conversion of chicken muscle to meat and factors affecting chicken meat quality: a review. Int J of Agronom and Agri Res 8: 1-20

Volk M, Malenšek J, Prevolnik M, Škrlep M, Šegula B, Čandek-Potokar M, Bavec M 2011: Differences in carcass and meat quality between organically reared cocks and capons. Agri Conspectus Scientificus 76: 153-155

Zawacka M, Murawska D 2013: Capon - whim or forgotten rarity? (in Polish) Ogólnopolski Informator Drobiarski. 264: 1-4 
Plate IV

Adamski M. et al.: Effects of the origin ... pp. 395-403

Group I

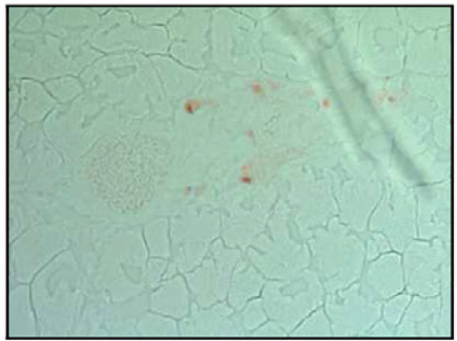

Number of fat cells (x): 3.5

Group II

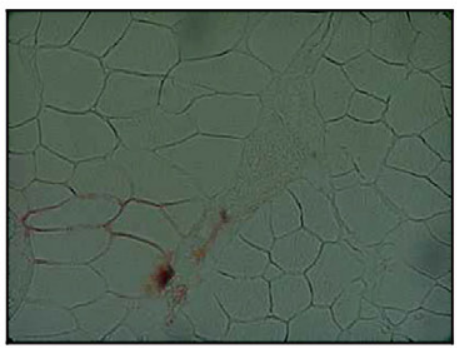

Number of fat cells (x):3.2

Group III

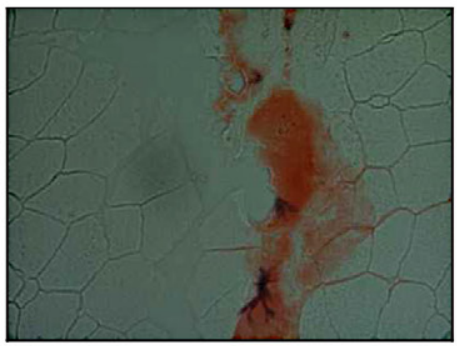

Number of fat cells (x): 3.5

Group IV

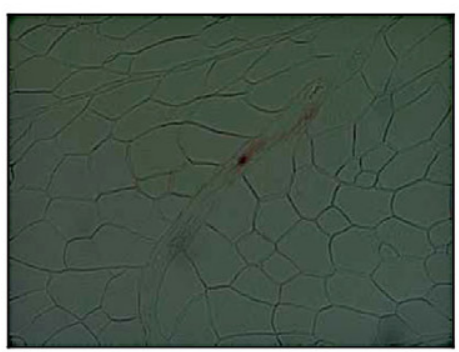

Number of fat cells (x): 4.0
Group V

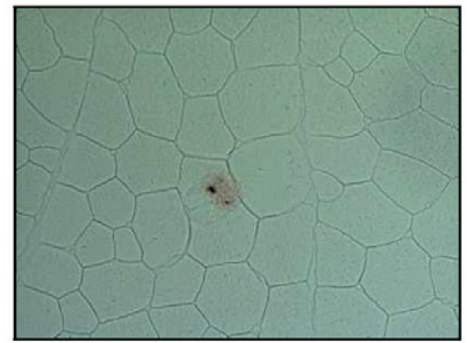

Number of fat cells (x): 3.7

Group VI

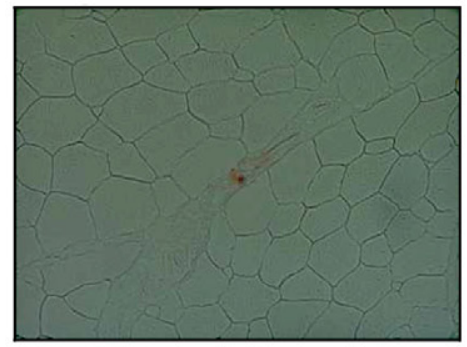

Number of fat cells (x): 4.3

Group VII

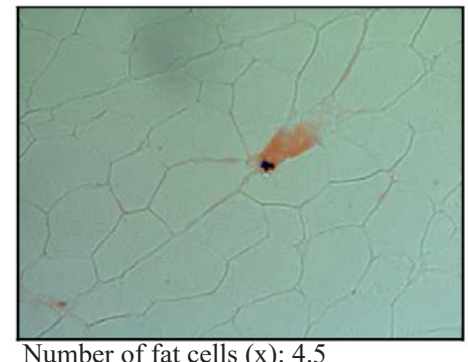

Group VIII

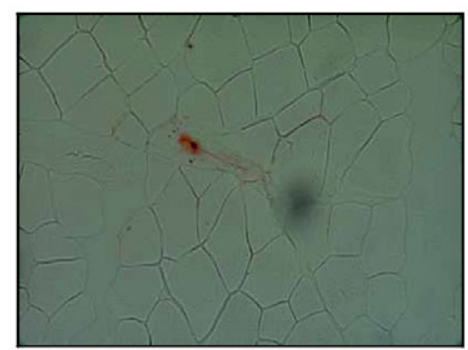

Number of fat cells (x): 4.5

Fig. 1. Mean number of fat cells* on $1 \mathrm{~mm}^{2}$ surface of the superficial breast muscle cross-section in the $18^{\text {th }}$ week of rearing in cockerels and capons (magnification $0.5 \times 20$ ) *no significant differences were found $(P \leq 0.05)$ 